\author{
Višnja Nesek Adam* \\ Jasna Mesarić**
}

\title{
COVID-19 I MASKE: ŠTO ZNAMO DO SADA?
}

\section{Sažetak}

SARS-CoV-2 pripada skupini betakoronavirusa koji uzrokuju bolest nazvanu COVID-19. Infekcija se prenosi kapljično, a moguć je prijenos i putem aerosola. Pandemija koronavirusa zahvatila je cijeli svijet, a broj oboljelih svakodnevno se povećava. Dok se ne pronađe učinkovito cjepivo i/ili lijekovi važno je provoditi sigurnosne zaštitne mjere kako bi se smanjilo širenje virusa. Održavanje fizičkog razmaka, higijena ruku i obveza nošenja zaštitnih maski tri su temeljne zaštitne mjere koje mogu pridonijeti sprečavanju širenja virusa. Učinkovitost pojedinih mjera još uvijek je predmet znanstvenih i neznanstvenih rasprava, dovodeći tako do proturječnih i zbunjujućih poruka široj javnosti. Iako u literaturi ne postoje kvalitetne studije koje bi potvrdile učinkovitost nošenja maski, većina objavljenih govori u prilog njihovoj učinkovitosti. U ovome radu dajemo pregled dosadašnjih istraživanja u pogledu učinkovitosti maski u sprečavanju širenja SARS-CoV-2 virusa.

Ključne riječi: COVID-19, zaštitne maske

\section{Uvod}

Koronavirus SARS-CoV-2 (engl. Severe Acute Respiratory Syndrome Coronavirus 2) pripada skupini betakoronavirusa koji izazivaju bolest nazvanu COVID-19. Otkriven je krajem 2019. u Kini i uzrokovao pandemiju koju je Svjetska zdravstvena organizacija (engl. World Health Organisation) 30. siječnja 2020. proglasila međunarodnom izvanrednom situacijom javnog zdravstva (SZO, 2020). Do kraja listopada 2020., prema podacima SZO zabilježeno je više od 45 milijuna oboljelih te više od 1,1 milijun umrlih (SZO, 2020). Prvi slučaj koronavirusa u Republici Hrvatskoj dijagnosticiran je 25. veljače 2020. Krajem listopada bilježimo više od 46000 oboljelih i 531 umrlu osobu (Hrvatski zavod za javno zdravstvo, 2020).

* prof. prim. dr. sc. Višnja Nesek Adam, dr. med., Klinička bolnica „Sveti Duh” Zagreb

** prof. dr. sc. Jasna Mesarić, dr. med., Libertas međunarodno sveučilište, jmesaric@libertas.hr 
Širenje virusa prvenstveno je uzrokovano kapljičnim prijenosom s čovjeka na čovjeka, bilo udisanjem kontaminiranih kapljica iz dišnog sustava ili prijenosom ruku u usta s kontaminiranih površina, a moguć je prijenos i putem aerosola ukoliko je osoba izložena tijekom dužeg vremena u zatvorenom prostoru visokoj koncentraciji aerosola koji sadrže virus. Radi se o vrlo zaraznom virusu čiji reprodukcijski broj iznosi između 1,4 do 7,2 (Liu et al., 2020). Budući da zasada ciljna terapija i cjepivo nisu raspoloživi, najvažnije oružje u borbi protiv virusa sprečavanje je njegova širenja. Pristup sprečavanju zasniva se na primjeni javnozdravstvenih načela suzbijanja zaraznih bolesti kao što je obavezno održavanje fizičkog razmaka od minimalno 1,5 $\mathrm{m}$ na otvorenom i $2 \mathrm{~m}$ u zatvorenom prostoru, učestalo pranje ruku, nošenje zaštitne maske te provođenje testiranja, traženja, otkrivanja i izolacija kontakata. Učinkovitost pojedinih mjera, a posebno obveza nošenja maski još je uvijek predmet znanstvenih i političkih rasprava. U nastavku dajemo pregled dosadašnjih istraživanja učinkovitosti maski u sprečavanju širenja SARS-CoV-2 virusa.

\section{Učinkovitost maski: za i protiv}

Sustavni pregledi literature o upotrebi zaštitnih maski ukazuju na relativni rizik (RR) smanjenja infekcije u rasponu od $6 \%$ do $80 \%$, uključujući i infekciju SARS-CoV-2. Tako širok raspon i nedosljednost u rezultatima posljedica je različitih uključnih $i$ isključnih kriterija, istraživane populacije (zdravstveno osoblje vs. opća populacija) te korištenje različitih vrsta maski. Iz tog razloga na samom početku pandemije SZO i Centar za kontrolu i prevenciju bolesti (engl. Center for disease control and prevention - CDC) nisu dali preporuke obaveznog nošenja maski u općoj populaciji, smatrajući da ne štite zdrave ljude od infekcije, a strahovalo se od moguće nestašice u opskrbi.

Glavni protivnici nošenja maski navode čitav niz razloga kojim ukazuju na njihovu malu učinkovitost u sprečavanju širenja infekcije, pa čak i štetnost. Smatraju da nošenje maske povećava rizik samokontaminacije čime se prevladava potencijalna korisnost, stvara osjećaj lažne sigurnosti, ograničava sloboda, ima štetne socijalne posljedice te nosi čitav niz drugih zdravstvenih rizika.

Međutim, stvarni problem nedonošenja jasnih preporuka obaveznog nošenja maski proizlazi iz metodologije znanstvenog istraživanja kojim bi se dokazala njihova učinkovitost u sprečavanju i/ili smanjenju širenja infekcije. Osim same maske (i vrste maske koju nosimo) postoji i čitav niz drugih čimbenika koji pridonosi učinkovitoj zaštiti od infekcije. Kao važni čimbenici u sprečavanju i/ili smanjenju širenja infekcije navode se socijalna i fizička udaljenost, otvorenost/zatvorenost prostora, cirkulacija i vlažnost zraka, zaštita očiju, higijena ruku i svih površina te je stoga teško osmisliti istraživanje koje bi moglo pružiti konačni dokaz da su maske učinkovite i kada i u kojim uvjetima ih koristiti. 
Povjerenje u maske počelo je rasti tijekom pandemije nakon nekoliko anegdotalnih zbivanja. Kao prvi primjer navodi se slučaj koji su objavili Hendrix et al. (2020). Radi se o dvojici frizera koji su nekoliko dana radili sa simptomima infekcije i kod kojih je kasnije dokazan COVID-19. Budući da su nosili masku nitko od 139 kontakata nije razvio bolest, no ukupno šest osoba s kojima su dijelili kućanstvo bez zaštitne maske, kroz nekoliko dana razvilo je COVID-19. Također je uočeno da na masovnim skupovima gdje se nosila maska nije došlo do skokova u infekciji u odnosu na skupove bez maski koji su vrlo brzo postali žarišta širenja infekcije. Na temelju toga CDC je donio preporuke nošenja maski na radnom mjestu za sve zaposlenike i klijente uz redovito praćenje temperature i ostalih simptoma infekcije (Centar za kontrolu i prevenciju bolesti, 2020). Tu je odluku slijedio i SZO kao i brojna regulatorna tijela većine država u Europi i ostatku svijeta.

Iako i dalje nemamo kvalitetnih studija koje bi potvrdile učinkovitost nošenja maski, većina objavljenih radova govori u prilog njihovoj učinkovitosti. Leffler et al. (2020) proveli su multivarijabilnu regresijsku analizu temeljem podataka objavljenih na Worldometer Database 5. svibnja 2020. (Europski centar za kontrolu i prevenciju bolesti, 2020), a vezano uz smrtnost od koronavirusa u više od 200 zemalja. Rezultati studije pokazali su da je tjedni porast smrtnosti u područjima gdje su maske bile obavezne ili barem preporučene, bio četiri puta niži u odnosu na druga područja. Niz drugih studija potvrdio je učinkovitost maski u smanjenju širenja infekcija i smrtnosti pod pretpostavkom pravilnog nošenja.

Međutim, problem drugih čimbenika koji se najčešće preporučaju zajedno s nošenjem maski, kao što je fizička distanca, ograničavanje okupljanja i slično i dalje su ograničavajući čimbenici u procjeni učinkovitosti maske kao samostalne preporuke.

Sustavni pregled i metaanaliza (Chu et al., 2020) koja je uključila 172 opservacijske studije iz 16 zemalja i 44 usporedne studije u bolničkim i izvanbolničkim uvjetima, na ukupno 25697 bolesnika, pokazala je da fizička distanca od jednog metra i više najviše pridonosi zaštiti od infekcije. Vezano za učinkovitost maski autori su naglasili da su izravni dokazi i dalje ograničeni jer optimalna upotreba maski, posebno N95 u zdravstvenim ustanovama te pamučne i kirurške maske u općoj populaciji, ovisi o kontekstualnim čimbenicima te da je potrebno provesti randomizirana istraživanja kako bi se dokazala njihova učinkovitost. Nadalje, ističu kako bi navedeni rezultati trebali poslužiti kao privremene smjernice za obvezu nošenja maski.

Istraživanje koje je provela kineska skupina istraživača (Fuk-Woo Chan et al., 2019) na životinjskom modelu, također je pokazalo učinkovitost maski u smanjenju prijenosa infekcije, ali i jačine bolesti. Kirurške maske postavljene su između dvaju kaveza s protokom zraka od zaraženih životinja prema zdravima. Takvim načinom zabilježeno je smanjenje beskontaktnog prijenosa virusa u više od 60 \% životinja. Ukupno dvije trećine životinja koje nisu bile zaštićene maskom zarazile su se unutar 
tjedna dana. Također je utvrđen veći učinak u sprečavanju prijenosa infekcije ukoliko je maska postavljena na kavez zaraženih životinja u odnosu na kavez zdravih životinja (15\% vs. $35 \%$ ). Utvrđene su blaže histopatološke promjene sluznice dišnog sustava i manje virusno opterećenje kod zaraženih životinja koje su bile zaštićene maskom. To istraživanje ukazuje na učinkovitost nošenja kirurške maske u sprečavanju prijenosa bolesti COVID-19, posebno kada maske nose zaražene osobe, ali ukazuje također na to da maske mogu štititi i od težih oblika bolesti.

\section{Vrste i izbor maski}

Ostaju još otvorena pitanja koja se odnose na izbor maski te kada i kako ih nositi (tablica 1). Zaštitne maske međusobno se razlikuju ovisno o razini filtracije, odnosno prema regulatornim standardima klasificiraju se prema razini filtriranja čestica veličine 0,3 mikrometra.

Tablica 1. Prikaz vrsta maski

\begin{tabular}{cccc}
$\begin{array}{c}\text { Vrste maski } \\
\text { Filtrirajuće } \\
\text { maske }\end{array}$ & $\begin{array}{c}\text { OFP2/FFP3 } \\
\text { N95/N99 }\end{array}$ & $\begin{array}{c}\text { Zaštita zdravstvenih djelatnika od kapljica i } \\
\text { aerosola. Filtrira najmanje 95 \% velikih i mali } \\
\text { čestica. }\end{array}$ & Dobro \\
$\begin{array}{c}\text { Kirurške } \\
\text { maske }\end{array}$ & $\begin{array}{c}\text { Troslojne kirurške } \\
\text { maske }\end{array}$ & $\begin{array}{c}\text { Filtrira čestice veće od } 20 \mu \text { m u promjeru, štite } \\
\text { osobu koja nosi masku od velikih čestica. Štiti } \\
\text { bolesnika od respiracijskih infekcija nositelja. }\end{array}$ & Slabo \\
$\begin{array}{c}\text { Platnene } \\
\text { maske }\end{array}$ & $\begin{array}{c}\text { Varijabilne (različitog } \\
\text { platna i slojeva tkanja) }\end{array}$ & $\begin{array}{c}\text { Opća populacija. Nisu namijenjene za slabo } \\
\text { respiracijsku zaštitu, ali mogu smanjiti prijenos } \\
\text { većih čestica. }\end{array}$ & - \\
\hline
\end{tabular}

Maske koje nose oznaku N95 i N99 (američki standard) označavaju stupanj zaštite od $95 \%$ odnosno $99 \%$. Maske FFP2 i FFP3 (oznake europskog standarda) imaju sličan stupanj zaštite, 94 \% odnosno 99 \% (Hrvatski zavod za javno zdravstvo, 2020). To su maske koje pružaju visok stupanj zaštite osobi koja nosi masku i namijenjene su prvenstveno zdravstvenom osoblju ili osobama koje borave u bliskom kontaktu sa zaraženim osobama (Hrvatski zavod za javno zdravstvo, 2020). Veličina virusa SARSCoV-2 koji uzrokuje pandemiju bolesti COVID-19 iznosi 50 - $200 \mathrm{~nm}$ što je ispod razini filtriranja navedenih maski.

Važno je naglasiti da još uvijek nije sa sigurnošću dokazano na koji se sve način prenosi COVID-19, odnosno koja je veličina čestica najvažnija za prijenos infekcije. Dakle, ako infekciju prenose i osobe bez simptoma (asimptomatske) onda kapljični prijenos nije najvažniji put prijenosa, već je vjerojatno da se infekcija prenosi aerosolom. U tom slučaju jedina su prava zaštita maske. 
Kao što je već naglašeno, filtrirajuće polumaske (FFP) ubrajaju se u osobnu zaštitnu opremu $(\mathrm{OZO})$ i namijenjene su prvenstveno zdravstvenom osoblju u zaštiti od čestica, kapljica i aerosola. Postoje maske s ventilom i bez ventila. Maske s ventilima filtriraju samo udahnuti zrak te stoga osiguravaju zaštitu samo osobi koja je nosi. Radi se o maskama s jednosmjernim ventilom što može biti problem tijekom pandemije jer postoji opasnost da je nositelj maske asimptomatski širitelj infekcije te na taj način izdiše nefiltrirani zrak u okolinu te potencijalno izlaže ostale osobe virusnim česticama.

U svojim preporukama CDC i SZO naglasili su da se maske s ventilima ili ventilacijskim otvorom ne smiju nositi kako bi se spriječilo širenje virusa osobe koja nosi masku (Centar za prevenciju i širenje bolesti, 2020; Svjetska zdravstvena organizacija, 2020). Maske bez ventila dobro prianjaju uz lice, imaju zadovoljavajući broj slojeva filtracijskog materijala i dobra retencijska svojstva te se smatra da su najbolji izbor za medicinsko osoblje u tijeku epidemije COVID-19.

Troslojne kirurške maske izvorno su uvedene kako bi zaštitile bolesnika od infekcija onih koje nose masku, a poslije su usvojene kako bi zaštitile i zdravstvene djelatnike od zaraze njihovih bolesnika. Budući da mogu filtrirati samo velike čestice te učinkovito smanjuju prijenos virusa koji se nalazi u respiracijskim kapljicama, ali ne i u aerosolima, upitna je njihova djelotvornost u sprečavanju širenja SARS-CoV-2 virusa.

Učinkovitost kirurške maske istraživano je u bolesnika s gripom. Istraživanje je utvrdilo važnu ulogu aerosola u prijenosu infekcije gripe, ali i potencijalnu učinkovitost kirurške zaštitne maske koju nose zaražene osobe u ograničavanju njezina širenja (Milton et al., 2013). Rezultati metaanalize provedene tijekom izbijanja SARS-a 2002. - 2004. također su pokazali da postoje dosljedni dokazi koji podupiru upotrebu običnih medicinskih maski (Jefferson, 2011.) Kineska skupina autora (Leung et al., 2020) $\mathrm{u}$ svom istraživanju prati količinu virusa u izdahnutom zraku s posebnim naglaskom na koronavirus. Utvrđeno je da su čak i aerosolizirane kapljice $(<5 \mu \mathrm{m})$ blokirane kirurškim maskama. Nasuprot tome, Seongman Bae et al. (2020) utvrdili su da kirurške maske, kao i maske od tkanine, nisu učinkovito filtrirale SARS-CoV-2 tijekom kašlja zaraženih bolesnika.

U veljači 2020. Svjetska zdravstvena organizacija donijela je preporuku o primjeni kirurških maski kao dovoljne zaštite u liječenju bolesnika s COVID-19 bolešću, a N95 bi se trebale koristiti samo u slučaju aerosoliziranih postupaka. Međutim, preporuke CDC-a su snažnije i ukazuju na potrebu nošenja N95 svih medicinskih djelatnika koji dolaze u kontakt s COVID-19 bolesnicima.

Platnene maske najviše se koriste u općoj populaciji i njihova učinkovitost filtriranja je niža od medicinskih maski, a ovisi prvenstveno o vrsti tkanine i načinu tkanju. Višeslojne platnene maske izrađene od vodootporne tkanine s gustim tkanjem 
mogu se koristiti za sprečavanje širenja zaraze u općoj populaciji bolesnih ili asimptomatskih zaraženih osoba.

Budući da je u početku pandemije bilo problema s dostupnosti medicinskih maski, brojni zdravstveni djelatnici nosili su platnene maske. Randomizirano istraživanje provedeno na više od 1000 zdravstvenih djelatnika tijekom četiri tjedna s ciljem da se utvrdi učinkovitost platnenih maski u odnosu na kirurške maske kod zdravstvenih djelatnika izloženih respiracijskim virusima, pokazalo je da platnene maske ne pružaju dovoljnu zaštitu te da loša filtracijska sposobnost platnenih maski, zadržavanje vlage te često ponovna upotreba mogu rezultirati povećanim rizikom infekcije (MacIntyre, 2015). Iz tog razloga platnene maske ne preporučaju se za zdravstvene djelatnike, već samo u općoj populaciji.

\section{Zaključak}

Usprkos nedostatku metodološki dobro osmišljenih randomiziranih studija, većina dosadašnjih istraživanja ukazuju na učinkovitost maski u sprečavanju i/ili smanjenju prijenosa infekcije SARS-CoV-2 virusa. Također, nošenje maski pridonosi podizanju svijesti o važnosti pridržavanja fizičke udaljenosti. Važno je naglasiti da se mora poštovati ispravno rukovanje s maskom (stavljanje, skidanje i nošenje) kao i čitav niz drugih preporuka kao što su pridržavanje općih higijenskih mjera i mjera fizičke udaljenosti, jer maske nisu dovoljne u sprečavanju i/ili smanjenju prijenosa infekcije te samo njihovo nošenje neće usporiti pandemiju.

\section{Literatura}

1. Seongman Bae, M. D. et al. 2020. Effectiveness of Surgical and Cotton Masks in Blocking SARS-CoV-2: A Controlled Comparison in 4 Patients. Ann Intern Med, 173 (1): $22-23$.

2. Centar za kontrolu i prevenciju bolesti. 2020. https://www.cdc.gov/coronavirus/ 2019ncov/community/organizations/businesses-employers.

3. Centar za kontrolu i prevenciju bolesti. 2020. https://www.cdc.gov/coronavirus/2019ncov/prevent-getting-sick/cloth-face-cover-guidance.html.

4. Chu, D. K. et al. 2020. COVID-19 Systematic Urgent Review Group Effort (SURGE) study authors. Physical distancing, face masks, and eye protection to prevent personto-person transmission of SARS-CoV-2 and COVID-19: a systematic review and metaanalysis. Lancet, 27, 395 (10242): 1973-1987.

5. European Centre for Disease Prevention and Control. Download today's data on the geographic distribution of COVID-19 cases worldwide. https://www.ecdc.europa.eu/ en/publications-data/download-todays-data-geographicdistribution-covid-19-casesworldwide. 
6. Fuk-Woo Chan, J. et al. 2019. Surgical Mask Partition Reduces the Risk of Noncontact Transmission in a Golden Syrian Hamster Model for Coronavirus Disease 2019 (COVID-19). Clin Infect Dis, 71 (16): 2139-2149.

7. Hendrix, M. J. et al. 2020. Absence of Apparent Transmission of SARS-CoV-2 from Two Stylists After Exposure at a Hair Salon with a Universal Face Covering Policy - Springfield, Missouri. Morb Mortal Wkly Rep, 17, 69 (28): 930-932.

8. Hrvatski zavod za javno zdravstvo. 2020. Koronavirus - najnoviji podatci. https://www. hzjz.hr/priopcenja-mediji/koronavirus-najnoviji-podatci.

9. Hrvatski zavod za javno zdravstvo. 2020. Klasifikacije i označavanje razine filtriranja kirurških i zaštitnih maski. https://www.hzjz.hr/sluzba-epidemiologija-zarazne-bolesti/ klasifikacije-i-oznacavanje-razine-filtriranja-kirurskih-i-zastitnih-maski/.

10. Hrvatski zavod za javno zdravstvo. 2020. Preporuke - maske. https://www.hzjz.hr/wpcontent/uploads/2020/03/Preporuke_maske_12_10_2020.pdf.

11. Jefferson, T. et al. 2011. Physical interventions to interrupt or reduce the spread of respiratory viruses. Cochrane Database Syst Rev, 7: CD006207.

12. Leffler, C. et al. 2020. Association of countrywide coronavirus mortality with demographics, testing, lockdowns, and public wearing of masks. https://www.ajtmh.org/content/journals/10.4269/ajtmh.20-1015.

13. Leung, N. H. L. et al. 2020. Respiratory virus shedding in exhaled breath and efficacy of face masks. Nat Med, 26: 676-680.

14. Liu, Y. et al. 2020. The reproductive number of covid-19 is higher compared to sars coronavirus. Journal of Travel Medicine, 13, 27.

15. MacIntyre, C. R. et al. 2015. A cluster randomized trial of cloth masks compared with medical masks in healthcare workers. BMJ Open, 5 (4): e006577.

16. Milton, D. K., Fabian, M. P., Cowling, B. J., Grantham, M. L. i McDevitt, J. J. 2013. Influenza virus aerosols in human exhaled breath: particle size, culturability, and effect of surgical masks. PLOS Pathog, 9: e1003205.

17. World Health Organisation. 2020. Statement on the second meeting of the International Health Regulations. https://www.who.int/news/item/30-01-2020-statement-on-the-second-meeting-of-the-international-health-regulations-(2005)-emergency-committeeregarding-the-outbreak-of-novel-coronavirus-(2019-ncov).

18. World Health Organisation. 2020. WHO Coronavirus Disease (COVID-19). https://covid19.who.int/.

19. World Health Organisation. 2020. Coronavirus disease (COVID-19): Masks. https:// www.who.int/emergencies/diseases/novel-coronavirus-2019/question-and-answershub/q-a-detail/q-a-on-covid-19-and-masks. 


\section{COVID-19 and masks: what do we know so far?}

\section{Abstract}

SARS-CoV-2 belongs to a group of beta-coronaviruses that cause a disease called COVID-19. The infection is transmitted by droplets and aerosol transmission is also possible. The coronavirus pandemic has spread all over the world, and the number of patients is increasing every day. Until effective vaccine and/or medication is founded it is important to implement safety precautions to reduce the spread of the virus. Maintaining physical distance, hand hygiene and the obligation to wear protective masks are three basic protective measures that can help prevent the spread of the virus. The effectiveness of certain measures is still the subject of scientific and unscientific debates, thus leading to contradictory and confusing messages to the general public. Although there are no quality studies in literature that would confirm the effectiveness of wearing masks, most published papers contributes to their effectiveness. In this paper, we provide an overview of previous research regarding the effectiveness of masks in preventing the spread of SARS-CoV-2 virus.

Key words: COVID-19, protective masks 